\title{
IMPLEMENTASI KURIKULUM 2013 DALAM PEMBELAJARAN PENJASORKES DITINJAU DARI STANDAR PROSES PEMBELAJARAN DI SMP KECAMATAN GOLEWA
}

\author{
Nikodemus Bate \\ Dosen Program Studi Pendidikan Jasmani Kesehatan dan Rekreasi STKIP Citra \\ Bakti \\ email: nico.dua21@gmail.com
}

\begin{abstract}
Abstrak
Penelitian ini bertujuan menganalisis kesesuaian penerapan Kurikulum 2013 (K-13) berdasarkan standar proses pembelajaran dalam pembelajaran penjasorkes di SMP Kecamatan Golewa. Penelitian ini termasuk dalam jenis penelitian survei dengan pendekatan kualitatif. Pengumpulan data menggunakan observasi, wawancara dan dokumentasi. Subjek dalam penelitian ini adalah guru penjasorkes sebanyak 3 (tiga) orang guru. Teknik analisis data menggunakan analisis deskriptif. Hasil penelitian ditemukan bahwa implementasi standar proses pembelajaran pada kegiatan inti: aspek mengamati, menanya, mengeksplorasi, mengasosiasi, dan mengkomunikasikan dalam pembelajaran penjasorkes di SMPN 4 Golewa, dan SMPN 5 Golewa belum semua aspek sesuai dengan standar proses pembelajaran pada Kurikulum 2013. Simpulan dalam penelitian ini yakni implementasi standar proses pembelajaran dalam pembelajaran penjasorkes yang dilakukan oleh guru penjasorkes di sekolah sasaran dinyatakan bahwa belum semua sekolah mengimplementasikannya sesuai dengan standar proses pembelajaran pada Kurikulum 2013.
\end{abstract}

\begin{abstract}
This study aims to analyze the suitability of the application of 2013 curriculum based on the standard of the learning process in physical education learning in junior high schools in Golewa District. This studywas included in the type of survey research with a qualitative approach. Data collection used wereobservation, interview and documentation. Subjects in this study were 3 (three) teachers of physical education. Data analysis technique used was descriptive analysis. The results of the study shows that the implementation of the learning process standard in the core activity: on the aspects of observing, asking, exploring, associating, and communicating in physical education learning at Golewa 4 State Junior High School, and Golewa 5 State Junior High School not all aspects in accordance with the learning process standard in 2013 curriculum.. The conclusionof this study is the implementation of the standard learning process in physical education learning conducted by physical education teachers in target schools stated that not all schools implemented it in accordance with the learning process standard in the 2013 curriculum.
\end{abstract}

Kata Kunci: Standar Proses, Implementasi Kurikulum, Pembelajaran Penjasorkes. 


\section{PENDAHULUAN}

Pendidikan merupakan aspek penting untuk meningkatkan dan mengembangkan sumber daya manusia (SDM). Dengan sumber daya manusia yang memadai, menusia diharapkan mampu membentuk watak dan kepribadian yang baik sehingga kelak mampu bersaing dengan manusia yang lain dalam segala bidang kehidupan. Manusia mampu menentukan pilihan untuk hidupnya. Pendidikan juga memberikan kontribusi yang signifikan dalam pembentukan kepribadian seorang individu. Hal ini sejalan dengan pernyataan yang disampaikan oleh Varol \& Imamoglu (2014) yakni "education...is an important and...comprehensive procces aims to develop individuals not only from cognitive aspect but also as a whole by contributing from psychological, social and physical aspects too". Kontribusi pendidikan membangun kepribadian seorang individu mencakup aspek kognitif, psikologi, sosial dan fisik, sehingga seorang individu bertumbuh dan berkembang sebagai seorang individu secara utuh. Oleh karena begitu pentingnya pendidikan, semua orang memberikan perhatian lebih. Arifin (2011) menyatakan bahwa untuk membagun sebuah bangsa, maka hal pertama yang harus dibangun adalah sistem pendidikannya. Pernyataan ini menegaskan bahwa pendidikan memegang peranan penting dalam membangun bangsa dan negara. Tidak ada hal lain yang lebih penting selain pendidikan. Sistem pendidikan Indonesia diatur dalam UU Nomor 20 tahun 2003 Tentang Sisdiknas. Dalam undang-undang tersebut memuat tujuan pendidikan nasional yang begitu luhur, yakni mengembangkan potensi peserta didik agar menjadikan anak bangsa yang beriman dan bertakwa kepada Tuhan yang Maha Esa, memiliki aklak mulia, sehat, berilmu, cakap, kreatif, mandiri dan menjadi Negara yang demokratis serta bertanggung jawab.

Pencapaian tujuan pendidikan nasional melibatkan banyak pihak untuk bersinergis dan memiliki tekad bersama agar membentuk manusia Indonesia menjadi manusia yang berkepribadian utuh. Untuk mencapai tujuan pendidikan nasional secara baik, benar dan utuh, para pakar di bidang pendidikan telah menyusun kurikulum sebagai langkah logis demi keterarahan, ketepatan serta efisiensi dalam pencapaian sebuah tujuan bersama. Arifin (2011) menyatakan bahwa untuk membangun pendidikan, maka hal pertama yang harus dibangun adalah sistem kurikulumnya. Penjelasan lanjut dari pernyataan ini adalah 1) kurikulum merupakan alat untuk mencapai pendidikan, 2) kurikulum menjadi sebuah disiplin ilmu yang wajib dipelajari oleh orang-orang yang berkecimpung dalam dunia pendidikan. Dalam perkembangan kurikulum di Indonesia telah memiliki beberapa kali perubahan dengan harapan agar kurikulum tersebut tetap relevan dengan perkembangan ilmu pengetahuan dan teknologi yang kian pesat. Perubahan tersebut menggambarkan secara jelas bahwa kurikulum merupakan alat pendidikan yang dinamis. Perubahan terjadi demi peningkatan kualitas pendidikan agar mampu menghasilkan 
manusia Indonesia yang mampu bersaing dengan bangsa-bangsa lain.

Pencapaian tujuan pendidikan nasional mengharuskan pemenuhan standar-standar yang telah ditatapkan bersama. Ada 8 (delapan) standar yang perlu dipenuhi oleh pelaku di bidang pendidikan. Standar-standar dalam pendidikan nasional adalah sebagai berikut: 1) standar isi, 2) standar proses, 3) standar kompetensi lulusan, 4) standar tenaga kependidikan, 5) standar sarana dan prasarana, 6) standar pengelolaan, 7) standar pembiayaan, 8) standar penilaian pendidikan (UU Nomor 20 tahun 2003 Tentang Sisdiknas, Pasal 35 ayat 1). Standar nasional pendidikan digunakan sebagai acuan dalam pengembangan kurikulum, tenaga pendidik, sarana dan prasarana, pengelolaan dan pembiayaan.

Kurikulum

merupakan

seperangkat rencana dan pengaturan mengenai tujuan, isi dan bahan pelajaran serta cara yang digunakan sebagai pedoman penyelenggaraan kegiatan pembelajaran untuk mencapai tujuan pendidikan tertentu (PP RI Nomor 32 Tahun 2013). Dari definisi ini menggambarkan bahwa pentingnya perencanaan dan proses untuk mencapai hasil. Lebih lanjut, Dwiyogo (2010) mendefinisi kurikulum sebagai sejumlah pengetahuan yang harus diselesaikan siswa agar mendapat ijasah atau mampu melewati suatu tingkatan. Kurikulum merupakan patokan atau standar serta cara-cara yang harus dipenuhi siswa agar mencapai tujuan dalam belajar. Pengembangan kurikulum dilaksanakan dengan berpatokan pada standar nasional pendidikan untuk mewujudkan tujuan pendidikan.

Kurikulum sangat diperlukan dalam rangka memajukan dan menyukseskan tujuan pendidikan. Oleh karena itu, pemerintah melalui Kementrian Pendidikan dan Kebudayaan menetapkan dan mengembangkan kurikulum pendidikan yang telah ada menjadi lebih baik lagi sehingga dapat memberikan dampak positif bagi peserta didik sendiri, masyarakat, maupun bangsa dan Negara. Standar proses pembelajaran dalam kegiatan inti pada kurikulum 2013 terdiri dari: mengamati, menanya, mengolah, menyajikan, menyimpulkan dan mencipta.

Standar proses pembelajaran merupakan salah satu tolok ukur mencapai tujuan pembelajaran. Sebagaimana Ginting (Fadlillah, 2014) menyatakan bahwa standar proses menjadi patokan bagi pendidik untuk merancang model dan metode dalam pelaksanaan pembelajaran yang melibatkan siswa. Lebih lanjut, Permendiknas Nomor 41 Tahun 2007 menyatakan bahwa standar proses merupakan standar pendidikan nasional yang berhubungan dengan pelaksanaan pembelajaran pada satuan pendidikan untuk mencapai standar kompetensi lulusan. Standar proses berisi kriteria minimal proses pembelajaran satuan pendidikan. Jika standar pembelajaran dilakukan dengan benar dan tepat, maka tujuan pembelajaran akan tercapai sesuai dengan yang diharapkan. Sukintaka (2004) menyatakan bahwa tujuan pendidikan jasmani diharapkan akan tercapai 
dengan hasil yang baik, jika perencanaan pembelajaran disiapkan dengan cermat dan pelaksanaannya sesuai dengan rencana tersebut. Difinubun dalam penelitian untuk tesis (2010) memperoleh hasil yakni penerapan kurikulum tingkat satuan pendidikan pada Sekolah Menengah Atas untuk mata pelajaran pendidikan jasmani, olahraga dan kesehatan belum maksimal dan belum menunjukkan peningkatan mutu pendidikan yang baik. Untuk menuju pada ketepatan implementasi standar proses dibutuhkan peran pendidik, yakni pendidik yang memiliki kualitas baik dan profesional serta paham akan langkah-langkah dalam sebuah proses pembelajaran. Sebagaimana Zhang \& Collis (Song \& Chen, 2012) menyatakan bahwa "a key to this fundamental curriculum change is the teachers themselves, the quality of their teaching, and their specific teaching methods". Guru sebagai pendidik dengan tugas utama mendidik, mengajar, membimbing, mengarahkan, melatih, menilai dan mengevaluasi peserta didik membutuhkan peningkatan profesional secara terus menerus. Keberhasilan mencapai tujuan sebuah pembelajaran sangat ditentukan oleh profesionalisme seorang guru. Di era kurikulum yang senantiasa mengalami pergeseran dan perubahan, penyelenggaraan pendidikan dan pembelajaran membutuhkan guru yang memiliki komitmen untuk belajar dan terus belajar serta mengaplikasikan pengetahuannya secara berkelanjutan. Guru yang mampu melaksanakan tugas dan juga mampu mengkolaborasikan berbagai strategi pembelajaran dapat membantu masalah siswa di kelas, khususnya dalam mata pelajaran pendidikan jasmani, olahraga dan kesehatan.

Menganalisis implementasi standar proses pembelajaran pada Kurikulum 2013 mengindikasikan bahwa standar proses merupakan hal yang penting dan menjadi keharusan bagi pendidik untuk menerapkannya secara baik dan benar. Dampak lanjutan dalam usaha mengalisis standar proses adalah membantu pendidik untuk merefleksikan akan penerapan pelaksanaan pembelajaran yang telah dilakukannya bersama peserta didik. Hal ini memberi efek yang signifikan bagi pendidik karena dengannya seorang pendidik dapat mengetahui akan apa yang telah dilakukannya dalam pembelajaran. Loughran (Lamb, Lane \& Aldous, 2012) menyatakan bahwa "reflection has been defined as 'a meaningful way of approaching learning abaout teaching so that a better understanding of teaching, and teaching about teaching, might develop". Merefleksikan pembelajaran yang telah dilaksanakan oleh guru memberi gambaran jelas bagi guru tersebut untuk berkembang lebih baik dalam proses pembelajaran, baik dalam hal strategi, metode dan hal-hal lainnya yang berkaitan dengan proses belajar-mengajar.

Kedudukan mata pelajaran pendidikan jasmani, olahraga dan kesehatan di dalam pendidikan nasional yang sebagaimana termuat dalam PP RI Nomor 32 Tahun 2013 yang merupakan penyempurnaan dari PP RI Nomor $19 \quad$ Tahun 2005, mengindikasikan bahwa mata pelajaran 
pendidikan jasmani, olahraga dan kesehatan merupakan salah satu mata pelajaran yang penting sekaligus memiliki beban tugas yang sama dengan mata pelajaran yang lain yakni mencapai tujuan pendidikan secara keseluruhan.

Sebagai bagian integral dari pendidikan secara keseluruhan, pendidikan jasmani, olahraga dan kesehatan memegang peranan penting dalam pembentukan manusia seutuhnya. Seperti yang disampaikan oleh Bailey (Erdvik et al., 2014) berkaitan dengan kontribusi pendidikan jasmani bagi peserta didik yakni " $P E$ may contribute to the development of fundamental movement skills, physical competence, social skills, social behaviours, self-esteem and pro-school attitudes in children". Mata pelajaran pendidikan jasmani, olahraga dan kesehatan menitikberatkan pada penggunaan aktivitas jasmani sebagai media untuk mencapai tujuan pembelajarannya. Suryobroto (2004) menyatakan bahwa pendidikan jasmani merupakan suatu proses pembelajaran yang didesain untuk meningkatkan kebugaran jasmani, mengembangkan keterampilan motorik, pengetahuan dan perilaku hidup aktif, dan sikap sportif melalui kegiatan jasmani. Lingkungan belajar diatur secara seksama untuk meningkatkan pertumbuhan dan perkembangan seluruh ranah, jasmani, psikomotor, kognitif dan afektif setiap siswa.

Pengalaman belajar yang disajikan akan membantu siswa untuk memahami mengapa manusia bergerak dan bagaimana cara melakukan gerakan secara aman, efisien, dan efektif. Selain itu, pengalaman tersebut dilaksanakan secara terencana, bertahap, dan berkelanjutan agar dapat meningkatkan sikap positif bagi diri sendiri sebagai pelaku, dan menghargai manfaat aktivitas jasmani bagi peningkatan kualitas hidup seseorang, sehingga akan terbentuk jiwa sportif dan gaya hidup aktif. Mata pelajaran pendidikan jasmani, olahraga dan kesehatan memberi sumbangan yang berarti dalam membentuk kepribadian seorang peserta didik. Proses pembelajaran yang melibatkan semua aspek yang diharapkan yakni aspek psikomotor, aspek kognitif dan aspek afektif. Seperti yang disampaikan oleh Graham (Syrmpas \& Digelidis, 2014) yakni learning in PE must be linked to three interdependent educational dimensions, motor, cognitive, and affective. Keberhasilan dalam pembelajaran penjasorkes sangat ditentukan oleh guru penjasorkes, guru yang memiliki kompetensi, guru yang mampu mengaplikasi standar proses pembelajaran dengan benar dan tepat, guru yang mampu menjadi fasilitator yang baik bagi peserta didik, guru yang memiliki kinerja kerja yang baik.

Berdasarkan pokok-pokok pikiran di atas, dalam ranah pembelajaran yang ditetapkan pada sebuah kurikulum untuk mengetahui hasil sebuah tujuan pembelajaran, maka menurut peneliti perlu adanya tinjauan sekaligus sebagai bahan refleksi, sejauh mana proses pembelajaran telah dilakukan sesuai dengan standar proses pembelajaran yang telah ditetapkan. Dengan ini judul penelitian tentang "Implementasi 
Kurikulum 2013 Dalam Pembelajaran Penjasorkes Ditinjau Dari Standar Proses Pembelajaran Di SMP Kecamatan Golewa hadir dihadapan kita semua.

Penelitian ini bertujuan mengkaji penerapan standar proses pembelajaran dalam pembelajaran penjasorkes pada Kurikulum 2013, (2) mengakaji sejauh mana penerapan standar proses pembelajaran dalam pembelajaran penjasorkes pada Kurikulum 2013.

\section{KAJIAN LITERATUR}

\begin{tabular}{lrr}
\multicolumn{1}{c}{ Belajar merupakan suatu } \\
aktivitas atau & suatu proses untuk \\
memperoleh & pengetahuan, \\
meningkatkan & keterampilan,
\end{tabular}
memperbaiki perilaku, sikap, dan mengokohkan kepribadian (Suyono \& Hariyanto, 2011). Lebih lanjut, Hamalik (2005) mendefinisi belajar yakni modifikasi atau memperteguh kelakuan melalui pengalaman. Definisi ini memiliki penjelasan lanjutan yakni belajar merupakan suatu proses, suatu kegiatan dan bukan suatu hasil atau tujuan. Belajar bukan hanya mengingat, akan tetapi lebih luas daripada itu, yakni mengalami. Hasil belajar bukan suatu penguasaan hasil latihan, akan tetapi perubahan kelakuan. Morgan et al (Ratumanan, 2004) mendefinisi belajar sebagai perubahan tingkah laku yang relative menetap dan terjadi sebagai latihan atau pengalaman. Sedangkan pembelajaran merupakan suatau upaya menciptakan kondisi yang memungkinkan siswa dapat belajar. Sukintaka (2004) menyatakan bahwa pembelajaran mengandung pengertian, bagaimana para guru mengajarkan sesuatu kepada peserta didik, tetapi di samping itu juga teradi peristiwa bagaimana peserta didik mempelajari. Sanjaya (2008) juga mendefinisikan pembelajaran sebagai usaha siswa mempelajari bahan sebagai akibat perlakuan guru. Pembelajaran menurut Undang-Undang Nomor 20 Tahun 2003 Tentang Sisdiknas pada bab 1 pasal 1 yakni pembelajaran sebagai proses interaksi peserta didik dengan pendidik dan sumber belajar pada suatu lingkungan belajar. Dengan demikian, belajar terjadi dua kejadian bersamaan dan dua pihak yang saling berinteraksi, yakni pihak pertama yang memberi dan pihak kedua yang menerima. Peristiwa tersebut dapat dikatakan terjadi proses interaktif edukatif. Proses interaktif edukatif tersebut diharapkan mampu mengubah tingkah laku yang relative permanen sebagai akibat dari latihan atau pengalaman.

Pembelajaran penjasorkes memberi kontribusi yang signifikan bagi perkembangan anak didik secara utuh dan komprehensif. Semua aspek perkembangan kepribadian anak mendapat tempat di dalam pembelajaran penjasorkes. Aspek kognitif, aspek afektif dan aspek psikomotor. Anak didik diperbiasakan untuk mengetahui tugas gerak tertentu sehingga dengannya anak tersebut memiliki motivasi dalam melakukan keterampilan gerak.Sebagaimana Melograno (Khomsin, 2001) menyatakan bahwa penjas adalah proses pemenuhan kebutuhan pribadi siswa yang meliputi aspek kognitif, afektif dan psikomotor yang secara 
eksplisit dapat terpuaskan melalui semua bentuk kegiatan jasmani yang diikutinya. Lebih lanjut, Mahendra (2003) menyatakan bahwa pendidikan jasmani merupakan proses pendidikan melalui aktivitas jasmani, permainan atau olahraga yang terpilih untuk mencapai tujuan pendidikan. Mutohir (2001) mengembangkan definisi pendidikan jasmani yang dilontarkan pada Lokakarya Nasional tentang Pembangunan Olahraga pada Tahun 1981 sebagai berikut; "pendidikan jasmani adalah suatu proses pendidikan seseorang sebagai orang perorangan atau anggota masyarakat yang dilakukan secara sadar dan sistematik melalui berbagai kegiatan jasmani untuk memperoleh pertumbuhan jasmani, kesehatan dan kesegaran jasmani, kemampuan dan keterampilan, kecerdasan dan perkembangan watak serta kepribadian yang harmonis dalam rangka pembentukan manusia Indonesia berkualitas berdasarkan Pancasila”. Sedangkan Rosdiani (2012) mendefinisi pendidikan jasmani sebagai proses pendidikan yang memanfaatkan ativitas jasmani yang direncanakan secara sistematik bertujuan untuk mengembangkan dan meningkatkan individu secara organik, neuromuscular, perseptual, kognitif dan emosional dalam kerangka sistem pendidikan nasional.

Menurut Sukintaka (2004), tujuan pembelajaran pendidikan jasmani mencakup empat ranah yakni: jasmani, psikomotor, afektif dan kognitif. Mahendra (2003) menyatakan bahwa tujuan pendidikan jasmani memberikan kesempatan kepada siswa untuk: a. Mengembangkan

pengetahuan

dan

keterampilan yang berkaitan dengan aktivitas jasmani, perkembangan estetika, dan perkembangan sosial.

b. Mengembangkan

kepercayaan diri dan kemampuan untuk menguasai keterampilan gerak dasar yang akan mendorong partisipasinya dalam aneka aktivitas jasmani.

c. Memperoleh dan mempertahankan derajat kebugaran jasmani yang optimal untuk melaksanakan tugas sehari-hari secara efisien dan terkendali.

d. Mengembangkan nilai-nilai pribadi melalui partisipasi dalam aktivitas jasmani baik secara kelompok maupun perorangan.

e. Berpartisipasi dalam aktivitas jasmani yang dapat mengembangkan

keterampilan sosial yang memungkinkan siswa berfungsi secara efektif dalam hubungan antar orang.

f. Menikmati kesenangan dan keriangan melalui aktivitas jasmani, termasuk permainan olahraga.

Lebih lanjut, Sallies \& McKenzie (Moreno at al., 2010) menyatakan bahwa "following from this appears fundamental to promote an active and healthy way of life obtained from physical education not only so that the student learns motor skills (to improve their performance) but also that they are motivated and enjoy their lessons". Dalam pembelajaran penjas siswa tidak hanya belajar keterampilan motorik, 
tetapi juga siswa termotivasi untuk belajar gerak dengan senang. Menurut Lutan (Saputra, 2012) tujuan pendidikan jasmani dan olahraga terdiri dari: (a) pembentukan gerak, (b) pembentukan prestasi, (c) pembentukan sosial, dan (d) pertumbuhan.

Guru merupakan jabatan atau profesi yang memerlukan keahlian khusus sebagai guru (Usman, 2010). Menurut Mulyasa (2005) pendidik harus memiliki kualifikasi akademik dan kompetensi sebagai agen pembelajaran, sehat jasmani dan rohani, serta memiliki kemampuan untuk mewujudkan tujuan pendidikan nasional. Lebih lanjut pengertian guru dalam Kemdikbud (2014) yakni guru adalah pendidik professional dengan tugas utama mendidik, mengajar, membimbing, mengarahkan, melatih, menilai, dan mengevaluasi peserta didik pada pendidikan anak usia dini jalur pendidikan formal, pendidikan dasar, dan pendidikan menengah. Usman (2010) mengurai tugas guru terdiri dari tiga tugas utama yakni:

1. Tugas dalam bidang profesi

Tugas guru sebagai profesi meliputi: mendidik, mengajar, dan melatih. Mendidik berarti meneruskan

dan

mengembangkan nilai-nilai

hidup. Mengajar berarti meneruskan dan

mengembangkan ilmu

pengetahuan dan teknologi.

Dan melatih berarti

mengembangkan

keterampilan-keterampilan

pada siswa.

2. Tugas dalam bidang kemanusiaan.

Tugas guru dalam bidang kemanusiaan berkenaan dengan posisi sebagai orang tua kedua bagi murid di sekolah. Guru harus menarik simpati sehingga ia menjadi idola bagi para siswanya. Pelajaran apapun yang diberikan, hendaknya dapat menjadi motivasi bagi siswanya dalam belajar.

3. Tugas dalam bidang kemasyarakatan.

Tugas guru dalam bidang kemasyarakatan berkenaan dengan eksistensinya untuk memberikan pencerahan bagi masyarakat di lingkungannya. Dari seorang guru diharapkan dapat memperoleh ilmu pengetahuan.

Adams \& Decey (Usman, 2010) menyatakan bahwa peran guru dalam proses belajar-mengajar antara lain guru sebagai pengajar, pemimpin kelas, pembimbing, pengatur lingkungan, partisipan, ekspeditor, perencana, supervisor, motivator, dan konselor.

Implementasi merupakan suatu penerapan ide, konsep, kebijakan atau inovasi dalam suatu tindak praktis sehingga memberikan dampak baik berupa perubahan pengetahuan, keterampilan, maupun nilai dan sikap (Susilo, 2006). Selanjutnya Usman (2002) menyatakan pendapatnya mengenai definisi tentang implementasi, yakni: implementasi diarahkan untuk kegiatan, tindakan, atau mekanisme sistem implementasi tidak hanya aktivitas, tetapi kegiatan dan untuk mencapai tujuan dari kegiatan yang direncanakan. Dengan demikian implementasi kurikulum merupakan suatu proses aktualisasi ide, konsep, kebijakan atau inovasi ke dalam bentuk tindakan praktis sehingga berimplikasi pada perubahan pengetahuan, 
keterampilan, dan tingkah laku seseorang.

Secara etimologis kurikulum berasal dari bahasa Yunani, yakni: curir yang artinya pelari dan curere yang berarti berpacu. Istilah kurikulum pada awalnya berhubungan dengan kegiatan olahraga pada jaman Romawi Kuno di Yunani dengan pengertian suatu jarak yang harus ditempuh oleh pelari (Dwiyogo, 2010). Secara terminologi, dalam sumber yang sama, kurikulum digunakan dalam dunia pendidikan dengan pengertian sejumlah pengetahuan yang harus ditempuh atau diselesaikan siswa guna mendapatkan suatu tingkatan atau ijasah. Lebih lanjut definisi kurikulum yang termuat dalam Undang-Undang Nomor 20 Tahun 2003 Tentang Sistem Pendidikan Nasional, yakni: kurikulum merupakan seperangkat rencana dan pengaturan mengenai tujuan, isi, dan bahan pelajaran serta cara yang digunakan sebagai pedoman penyelenggaraan kegiatan pembelajaran untuk mencapai tujuan pendidikan tertentu. Berdasarkan definisi tersebut di atas tentang kurikulum, maka dapat disimpulkan bahwa kurikulum merupakan rencana dan pengaturan mengenai tujuan, isi, dan bahan pelajaran serta cara yang digunakan untuk kegiatan pembelajaran dengan mempertimbangkan perkembangan ilmu pengetahuan dan teknologi sehingga mampu menjawabi kebutuhan tujuan pendidikan nasional.

Kurikulum 2013 merupakan kurikulum berbasis kompetensi. Kurikulum berbasis kompetensi adalah outcomes-based curriculum, untuk itu pengembangan kurikulum diarahkan pada pencapaian kompetensi yang dirumuskan dari SKL. Demikian pula penilaian hasil belajar dan hasil kurikulum di ukur dari pencapaian kompetensi. Fadlillah (2014) menyatakan bahwa kurikulum 2013 adalah sebuah kurikulum yang dikembangkan untuk meningkatkan dan menyeimbangkan kemampuan soft skills dan hard skills yang berupa sikap, keterampilan, dan pengetahuan. Tujuan pengembangan kurikulum 2013 adalah mempersiapkan insan Indonesia agar memiliki kemampuan hidup sebagai pribadi dan warga Negara yang beriman, produktif, kreatif, inovatif, dan aktif serta mampu berkontribusi pada kehidupan bermasyarakat, berbangsa, bernegara dan peradaban dunia (Kemdikbud, 2013). Lebih lanjut, Fadlilah (2014) mengidentifikasi tujuan kurikulum 2013 adalah sebagai berikut:

1. Meningkatkan mutu pendidikan dengan menyeimbangkan hard skills dan soft skills melalui kemampuan sikap, keterampilan, dan pengetahuan dalam rangka menghadapi tantangan global yang terus berkembang.

2. Membentuk dan meningkatkan sumber daya manusia yang produktif, kreatif, dan inovatif sebagai modal pembangunan membangun bangsa dan Negara.

3. Meringankan tenaga pendidik dalam menyampaikan materi dan menyiapkan administrasi mengajar.

4. Meningkatkan peran serta pemerintah pusat dan daerah serta warga masyarakat secara seimbang dalam menentukan dan mengendalikan kualitas dalam pelaksanaan kurikulum di tingkat satuan pendidikan. 
5. Meningkatkan persaingan yang sehat antar-satuan pendidikan tentang kualitas pendidikan yang akan dicapai.

Standar proses pendidikan merupakan standar nasional pendidikan yang berkaitan dengan pelaksanaan pembelajaran pada satu satuan pendidikan untuk mencapai standar kompetensi lulusan (PP Nomor 19 Tahun 2005 Pasal 1 Ayat 6). Lebih lanjut, Mulyasa (2013) menjelaskan bahwa standar proses adalah kriteria mengenai pelaksanaan pembelajaran pada satu satuan pendidikan untuk mencapai standar kompetensi lulusan. Dalam sumber yang sama dijelaskan tentang garis besar standar proses sebagai berikut:

1. Proses pembelajaran pada satuan pendidikan diselenggarakan secara interaktif, inspiratif, menyenangkan, menantang, memotivasi peserta didik untuk berpartisipasi aktif, serta memberikan ruang yang cukup bagi prakarsa, kreativitas, dan kemandirian sesuai dengan bakat, minat, dan perkembangan fisik serta psikologis peserta didik.

2. Setiap satuan pendidikan melakukan perencanaan proses pembelajaran, pelaksanaan proses pembelajaran, penilaian hasil pembelajaran, dan pengawasan proses pembelajaran untuk terlaksananya proses pembelajaran yang efektif dan efisien.

3. Perencanaan pembelajaran merupakan penyusunan rencana pelaksanaan pembelajaran untuk setiap muatan pembelajaran.

Untuk mencapai tujuan kurikulum 2013, maka penerapan proses pembelajaran dikembangkan atas prinsip siswa aktif. Pendekatan pembelajaran (Kemdikbud, 2013) adalah pendekatan ilmiah (scientific approach) melalui kegiatan-kegiatan tersebut di bawah ini:

1. Mengamati.

Mengamati

dalam pembelajaran penjasorkes diartikan bahwa peserta didik diajak untuk melihat, baik melihat melalui audio visual ataupun melalui gerakangerakan yang akan dipraktekkan atau di demonstrasikan oleh guru. Hal ini dimaksudkan untuk mengeksplorasi daya pikir peserta didik, sampai sejauh mana penguasaan awal tentang materi yang akan diberikan. Selain mengamati video pembelajaran ataupun mangamati aktifitas manusia, seorang guru bisa memberikan contoh gambar baik foto maupun ilustrasi, yang berhubungan dengan materi pembelajaran yang akan disampaikan.

2. Menanya (questioning).

Maksud dari pendekatan scientific pada tahap ini adalah untuk memudahkan siswa mengetahui tentang makna dari sebuah gerakan atau teknik dasar dari materi yang akan disampaikan. Dalam tahap bertanya ini terjadi dua arah maksudnya guru memberikan kesempatan sebanyak- 
banyaknya kepada peserta didik untuk menanyakan apa yang dia ketahui, dan dalam kesempatan yang sama guru harus menjawab sejelas mungkin sampai peserta didik memahaminya. Setelah semua pertanyaan dari peserta didik terjawab dengan jelas, maka giliran guru yang akan memberikan pertanyaan kepada peserta didik. Hal ini dimaksudkan supaya guru mengetahui sejauh mana materi awal yang dikuasai peserta didik, sehingga guru dengan mudah dalam merancang metode dan langkah pembelajaran selanjutnya.

3. Mencoba (experimenting).

Pada tahap ini peserta didik diberi kesempatan untuk mencoba melakukan gerakan hasil pengamatan tayangan video ataupun contoh yang didemonstrasikan oleh guru. Dalam proses mencoba ini guru harus memberikan kesempatan kepada semua peserta didik untuk mempraktekkan sebuah keterampilan gerak sebanyakbanyaknya. Tujuannya adalah semua peserta didik mempunyai pengalaman gerak yang banyak. Dalam pembelajaran penjasorkes tahapan mempraktekkan merupakan tahapan yang wajib dilaksanakan sesuai dengan kemampuan motorik masing-masing siswa, karena benar dan tidaknya pola gerak dasar lokomotor bisa dilihat dan diamati serta dinilai dari gerakan. Dalam tahap ini guru memberikan kebebasan untuk mempraktekkan apa yang peserta didik pahami dalam langkah pembelajaran sebelumnya.

Fungsi guru pada tahap ini tidaklah dominan, tetapi hanya melakukan pengamatan dan mencatat tentang apa yang kurang dan mesti dikoreksi, ataupun memberikan apresiasi bagi peserta didik yang mampu melakukan sesuai dengan teknik sebenarnya.

4. Mengolah.

Setelah peserta didik mencoba melakukan sebuah keterampilan gerak, tahap selanjutnya melakukan pengulangan-pengulangan keterampilan gerak terutama pada bagian-bagian keterampilan gerak yang belum dikuasai. Pada tahap ini peserta didik harus memperhatikan dengan benar tahapan-tahapan gerak yang dilakukan apakah sudah sesuai dengan gerakan pada tayangan video/yang telah didemonstrasikan oleh guru atau belum.

5. Menyaji.

Pada tahap ini peserta didik diberi kesempatan kembali oleh guru untuk menyajikan keterampilan gerak hasil dari latihan yang dilakukan pada tahapan mengolah. Di sini guru harus memperhatikan semua tahap-tahap gerak yang dilakukan oleh peserta didik selama penyajian keterampilan gerak. 
6. Menalar (associating).

Penalaran secara umum adalah proses berpikir yang logis dan sistematis atas fakta-fakta empiris yang dapat diobservasi untuk memperoleh simpulan berupa pengetahuan. $\quad \mathrm{Di}$ sini penalaran dapat bermakna penyerupaan (associating) dan juga dapat bermakna akibat (reasoning).

Pada tahap ini, penalaran bisa dilaksanakan dengan berbagai metode diantaranya adalah berdiskusi. Dengan diskusi maka akan banyak pendapat yang dikemukakan oleh peserta didik dengan berbagai macam alasan. Posisi seorang guru dalam tahap ini hanyalah sebagai mediator sampai semua pendapat bisa dikemukakan. Tahap berikutnya adalah guru menyimpulkan berbagai macam pendapat dari peserta didik. Pada tahap ini peserta didik sudah mampu memahami tahap-tahap gerak yang seharusnya dilakukan sesuai dengan pola gerak yang benar.

7. Mencipta.

Setelah peserta didik memahami betul pola gerak yang harus dilakukan dalam sebuah keterampilan gerak, maka tahap berikutnya adalah peserta didik semaksimal mungkin melakukan gerakan sesuai dengan pola gerak yang benar, bahkan pada tahap ini peserta didik sudah mampu melakukan variasi dan kombinasi teknik gerak yang dilakukan.

Dalam silabus pembelajaran penjasorkes pada bagian inti kegiatan pembelajaran disebutkan bahwa proses pembelajaran melalui kegiatan-kegiatan ini: mengamati, menanya, eksplorasi, asosiasi, dan mengkomunikasikan.

\section{METODE PENELITIAN}

Penelitian ini merupakan penelitian survey dengan pendekatan kualitatif. Penelitian ini berusaha mengungkapkan kondisi nyata tentang penerapan standar proses pembelajaran dalam pembelajaran penjasorkes yang dilaksanakan oleh guru pendidikan jasmani, olahraga dan kesehatan pada Sekolah Menengah Pertama yang menerapkan Kurikulum 2013 di Kecamatan Golewa. Subjek dalam penelitian ini adalah guru pendidikan jasmani, olahraga dan kesehatan Tingkat SMP di Kecamatan Golewa yang terdiri dari 3 (tiga) orang guru. Peran peneliti dalam penelitian ini adalah peneliti sebagai informen kunci atau human instrument.

Teknik analisi data yang digunakan adalah teknik analisis deskriptif, yaitu memaparkan semua data yang diperoleh dalam bentuk narasi atau kata-kata, diolah kemudian ditabulasikan, data dipilah-pilah atau dikelompokkan menurut penerapan standar proses pada kurikulum yang berlaku. Setelah data dikelompokkan dan diolah, maka ditarik simpulan dari penelitian.

\section{HASIL PENELITIAN DAN PEMBAHASAN}

Hasil Penelitian 
$\begin{array}{cccc}\text { Pengelompokkan data tentang } & \text { pembelajaran pada Kurikulum } 2013 \\ \text { penerapan } & \text { standar } & \text { proses } & \text { terlihat dalam tabel berikut ini: }\end{array}$

Tabel 1

Kesesuaian Penerapan Standar Proses Pembelajaran Pada Kurikulum 2013 di SMPN 1 Golewa, SMPN 4 Golewa, dan SMPN 5 Golewa

No Standar Proses K13

\begin{tabular}{|c|c|c|}
\hline $\begin{array}{l}\text { Kesesuaian } \\
\text { Proses }\end{array}$ & Penerapan & Standar \\
\hline SMP & SMPN4 & SMPN 5 \\
\hline $\begin{array}{l}\text { Belum } \\
\text { Sesuai }\end{array}$ & $\begin{array}{ll}\text { Sesua } & \text { Belum } \\
i & \text { Sesua } \\
\end{array}$ & $\begin{array}{ll}\text { Sesua } & \text { Belum } \\
i & \text { Sesua }\end{array}$ \\
\hline
\end{tabular}

Rencana Pelaksanaan Pembelajaran (RPP)pada Komponen Kegiatan Inti

1. Mengamati

2. Menanya

3. Mengeksplorasi

4. Mengasosiasi

5. Mengkomunikasikan

$\begin{array}{lllll}\sqrt{ } & \sqrt{ } & & & \sqrt{ } \\ \sqrt{ } & \sqrt{ } & & \sqrt{ } & \\ \sqrt{ } & \sqrt{ } & \sqrt{ } & \\ \sqrt{ } & \sqrt{ } & \sqrt{ } & \\ & \sqrt{ } & & \sqrt{ }\end{array}$

Hasil Pengamatan Suasana Kegiatan Pembelajaran Penjasorkes di Lapangan

1. Mengamati

2. Menanya

3. Mengeksplorasi

4. Mengasosiasi

5. Mengkomunikasikan

Hasil Wawancara Peneliti dengan Guru Penjasorkes dan Peserta Didik

1. Mengamati

2. Menanya

3. Mengeksplorasi

4. Mengasosiasi

5. Mengkomunikasikan

Sumber: Data Hasil Olahan Penulis Tahun 2017.

Berdasarkan data dari tabel 2 sebelumnya terlihat bahwa penerapan standar proses pembelajaran pada Kurikulum 2013 dalam pembelajaran penjasorkes yang dilakukan oleh guru penjasorkes yang sesuai adalah guru penjasorkes SMPN 1 Golewa. Hal ini dikarenakan guru penjasorkes SMPN 1 Golewa telah memenuhi semua kegiatan, baik pada aspek mengamati, menanya, mengeksplorasi, mengasosiasi dan mengkomunikasikan.
Penerapan standar proses pembelajaran pada Kurikulum 2013 yang belum sesuai adalah SMPN 4 Golewa dan SMPN 5 Golewa, hal tersebut dapat diuraikan, sebagai berikut:

1. RPP yang disiapkan oleh guru penjasorkes di SMPN 4 Golewa belum memenuhi aspek mengeksplorasi, mengasosiasi, dan mengkomunikasikan. RPP yang disiapkan oleh guru 
penjasorkes di SMPN 5

Golewa belum memenuhi aspek mengamati dan mengkomunikasikan.

2. Hasil pengamatan peneliti dalam pembelajaran penjasorkes terlihat bahwa pembelajaran penjasorkes di SMPN 4 Golewa belum memenuhi aspek menanya, dan aspek mengasosiasi. Secara khusus guru penjasorkes di SMPN 5 Golewa, meskipun pada RPP tampak bahwa guru tidak menyiapkan diri secara baik dengan menguraikan setiap aspek, namun dalam kegiatan pembelajaran ternyata guru sudah memenuhi semua aspek baik aspek mengamati, menanya, mengeksplorasi, mengasosiasi, maupun mengkomunikasikan.

3. Hasil wawancara peneliti dengan guru penjasorkes dan peserta didik terlihat bahwa guru penjasorkes di SMPN 1 Golewa, SMPN 4 Golewa, dan SMPN 5 Golewa konsisten dengan hasil pengamatan sebelumnya.

\section{Pembahasan}

Hasil penelitian ditemukan bahwa penerapan standar proses pembelajaran yang dilakukan oleh guru penjasorkes pada kegiatan inti pembelajaran, yakni: aspek mengamati, menanya, mengeksplorasi, mengasosiasi, dan mengkomunikasikan dalam Kurikulum 2013 di 3 (tiga) sekolah sasaran belum semuanya sesuai.
Hasil penelitian tersebut di atas menegaskan bahwa peran guru sangat penting dalam kegiatan pembelajaran di lapangan, apakah penerapan Kurikulum 2013 sesuai dengan standar proses pembelajaran atau tidak terletak pada peran guru itu sendiri. Hasil penelitian pada sekolah-sekolah yang menerapkan Kurikulum 2013 tersebut relevan dengan pendapat yang dikemukakan oleh Adams \& Decey (Usman, 2010) yang menyatakan bahwa peran guru antara lain: guru sebagai pengajar, guru sebagai pemimpin kelas, guru sebagai pembimbing, guru sebagai pengatur lingkungan, guru sebagai partisipan, guru sebagai ekspeditor, guru sebagai perencana, guru sebagai supervisor, guru sebagai motivator, dan guru sebagai konselor.

Sebagai pengajar, pemimpin kelas, pembimbing, pengatur lingkungan, partisipan, ekspeditor, perencana, supervisor, motivator, dan konselor, maka kesiapan guru yang mumpuni sangat membantunya dalam melaksanakan kegiatan pembelajaran penjasorkes di lapangan. Untuk itu guru harus benar-benar memahami tentang langkah-langkah dalam standar proses pembelajaran pada Kurikulum 2013, sehingga pengimplementasiannya peran guru dapat dimaksimalkan.

\section{PENUTUP}

\section{Simpulan}

Hasil penelitian tentang Implementasi Kurikulum 2013 dalam pembelajaran penjasorkes ditinjau dari standar proses pembelajaran dapat disimpulkan sebagai berikut:

1. Implementasi standar proses dalam pembelajaran penjasorkes yang dilakukan oleh guru penjasorkes di 
sekolah sasaran dinyatakan bahwa belum semua sekolah mengimplementasikannya sesuai dengan standar proses pembelajaran pada Kurikulum 2013.

2. Implementasi standar proses pembelajaran pada Kurikulum 2013 dalam pembelajaran penjasorkes di SMPN 4 Golewa, guru penjasorkes belum menyiapkan RPP secara lengkap dengan tidak menguraikan aspek mengeksplorasi, aspek mengasosiasi, dan aspek mengkomunikasikan. Dalam pembelajaran di lapangan, guru belum memenuhi aspek menanya dan mengeksplorasi. Guru SMPN 5 Golewa belum menyiapkan RPP secara lengkap dengan tidak menguraikan aspek mengamati dan aspek mengasosiasi. Dalam pembelajaran di lapangan, guru belum memenuhi aspek menanya Saran dan aspek mengeksplorasi.

Berdasarkan hasil penelitian yang telah dijelaskan sebelumnya, maka peneliti merekomendasikan beberapa saran, sebagai berikut:

1. Bagi guru penjasorkes sekolah sasaran yang telah menerapkan standar proses pembelajaran sesuai dengan standar proses pembelajaran pada Kurikulum 2013, kiranya mempertahankan kualitas pembelajaran yang ada sehingga standar kompetensi lulusan dalam pembelajaran penjasorkes tetap tercapai.

2. Bagi guru penjasorkes sekolah sasaran yang belum semuanya menerapkan standar proses pembelajaran pada Kurikulum 2013, kiranya hasil penelitian ini dapat

$\begin{array}{lr}\text { menjadi masukan } & \text { demi } \\ \text { perbaikan } & \text { kualitas } \\ \text { pembelajaran } & \text { sehingga } \\ \text { standar kompetensi } & \text { lulusan } \\ \text { dapat tercapai. } & \end{array}$

\section{DAFTAR PUSTAKA}
Arifin, Z. (2011). Konsep Dan Model Pengembangan Kurikulum (Konsep, Teori, Prinsip, Prosedur, Komponen, Pendekatan, Model, Evaluasi \& Inovasi). Bandung: PT Remaja Rosdakarya.

Depdiknas RI. (2013). PP RI Nomor 32 Tahun 2013 Tentang Perubahan Atas PP Nomor 19 Tahun 2005 Tentang Standar Nasional Pendidikan. Jakarta: Depdiknas. (2003). UU RI Nomor 20 Tahun 2003 Tentang Sistem Pendidikan Nasional. Jakarta: Depdiknas.

(2005). PP RI Nomor 19 Tahun 2005 Tentang Standar Nasional Pendidikan. Jakarta: Depdiknas.

(2007). Permendiknas RI Nomor 41 Tahun 2007 Tentang Standar Proses Untuk Satuan Pendidikan Dasar Dan Menengah. Jakarta: Depdiknas.

Difinubun, H. (2010). Implementasi Kurikulum Tingkat Satuan Pendidikan SMA Pada Mata Pelajaran Pendidikan Jasmani Olahraga Dan Kesehatan (Tesis yang tidak dipublikasikan), Universitas Negeri Surabaya, Surabaya. 
Dwiyogo, W. D. (2010). Pengembangan

Kurikulum. Malang: Wineka Media.

Erdvik, Burchard, I., Øverby, Cecilie, N., Haugen \& Tommy. (2014). Students' selft-determined motivation in physical education and intention to be physically active after graduation: The role of perceived competence and identity. Journal of Physical Education and Sport. 14 (2), Art 35. Pp. $232-241$.

Fadlilah, M. (2014). Implementasi Kurikulum 2013 Dalam Pembelajaran SD/MI. SMP/MTs, \& SMA/MA. Yogyakarta: Ar-Ruzz.

Hamalik, Oemar. 2007. Kurikulum dan Pembelajaran. Jakarta : Bumi Aksara.

Kemdikbud. (2013). Materi Pelatihan Guru Implementasi Kurikulum 2013 SMP Penjasorkes. Jakarta: Kemdikbud.

(2014). Pedoman Penilaian Prestasi Kerja Guru, Kepala Sekolah, Dan Guru Yang Diberi Tugas Tambahan. Jakarta: Kemdikbud.

Khomsin. 2001. "Paradigma Baru Pendidikan Jasmani di Indonesia Dalam Era Reformasi". Makalah disampaikan pada acara konvensi Nasional Indonesia, Hotel Indonesia, Jakarta.

Kurinasi, I., \& Sani, B. (2014). Implementasi Kurikulum 2013 Konsep \& Penerapan. Surabaya: Kata Pena.
Lamb, P., Lane, K., \& Aldous, D. (2012). Enhancing the spaces of reflection: A buddy peer-review process within physical education initial teacher education. European Physical Education Review. 19 (1) 21 - 38. Doi: $10.1177 / 1356336 \times 12457293$

Mahendra, A. (2003). Falsafah Pendidikan Jasmani. Jakarta: Direktorat Pendidikan Luar Biasa.

Moreno, J. A., Cutre, G. D., Albo, M. J., \& Eduardo, C. (2010). Motivation and performance in physical education: An experimental test. Journal of Sports Science and Medicine 9, 79-85

Mulyasa, E. (2005). Menjadi Guru Profesional. Bandung: PT Remaja Rosda Karya. (2013). Pengembangan dan Implementasi Kurikulum 2013. Bandung: PT Remaja Rosda Karya.

Mutohir, H. T. C. (2002). GagasanGagasan Tentang Pendidikan Jasmani dan Olahraga. Surabaya: Unesa University Press.

Ratumanan, T. G. dan Laurens, Theresia. 2006. Evaluasi Hasil Belajar Yang Relevan Dengan Kurikulum Berbasis Kompetensi. Surabaya: Unesa University Press.

Rosdiani, D. (2012). Model Pembelajaran Langsung dalam Pendidikan Jasmani dan Olahraga. Bandung: Alfabeta.

Sanjaya, W. (2015). Kurikulum dan Pembelajaran (Teori dan Praktik Pengembangan Kurikulum 
Tingkat Satuan Pendidikan (KTSP)). Jakarta: Prenadamedia Group.

Saputra, H. Y. M. (2012). Konsep Dasar Pendidikan Jasmani dan Kesehatan Bagi Guru Madrasah Ibtidaiyah. Jakarta: Direktorat Jenderal Pendidikan Islam Kementrian Agama RI.

Song, L., \& Chen, J. (2012). University students' conceptions of an excellent physical education teacher in China. European Physical Education Review. 19 (1) $110-126$.

Sukintaka. (2004). Teori Pendidikan Jasmani. Filosofi, Pembelajaran \& Masa Depan. Bandung: Yayasan Nuansa Cendekia.

Suryobroto, A. S. (2004). Peningkatan Kemampuan Manajemen Guru Pendidikan Jasmani. Jurnal Pendidikan Jasmani Indonesia. Volume 1, No. 1.

Suyono dan Hariyanto. (2011). Belajar dan Pembelajaran (Teori dan Konsep Dasar).

Syrmpas, I., \& Digelidis, N. (2014). Physical education student teachers' experiences with and perceptions of teaching styles. Journal of Physical Education and Sport. Art 9, pp. 52 - 59.

Usman, M. U. (2010). Menjadi Guru Profesional. Bandung: Remaja Rosdakarya.

Varol, Y. K., \& Imamoglu, F. (2014). Comparatively analyzing the physical education curriculum in elementary education according to teacher opinions in Turkey and England. Journal of Physical Education and Sport. Art 16, pp. 98 - $105 . \quad$ Doi: 10.7752/jpes.2014.0101. 